NBER WORKING PAPER SERIES

\title{
WHEN DOES IT PAY TO DELAY SOCIAL SECURITY? THE IMPACT OF MORTALITY, INTEREST RATES, AND PROGRAM RULES
}

\author{
John B. Shoven \\ Sita Nataraj Slavov \\ Working Paper 18210 \\ http://www.nber.org/papers/w18210
NATIONAL BUREAU OF ECONOMIC RESEARCH
1050 Massachusetts Avenue
Cambridge, MA 02138
July 2012

This research was supported by Sloan Foundation grant number 2011-10-18, "Series vs. Parallel Retirement Income Strategies." The authors are grateful to Phoebe Yu for outstanding research assistance; to Jason Scott and David Weaver for helpful discussion and comments; and to Steve Goss, Michael Morris, and Alice Wade of the Social Security Administration for providing the cohort life tables used in this paper. The first author is a member of the board of directors of Financial Engines, a Nasdaq-listed company which assists individuals with retirement planning. Financial Engines provided no financial support for this research. The authors are doing related research that is supported by a Social Security Administration grant to the National Bureau of Economic Research. The views and approaches in this paper are solely those of the authors. The views expressed herein are those of the authors and do not necessarily reflect the views of the National Bureau of Economic Research.

NBER working papers are circulated for discussion and comment purposes. They have not been peerreviewed or been subject to the review by the NBER Board of Directors that accompanies official NBER publications.

(C) 2012 by John B. Shoven and Sita Nataraj Slavov. All rights reserved. Short sections of text, not to exceed two paragraphs, may be quoted without explicit permission provided that full credit, including (C) notice, is given to the source. 
When Does It Pay to Delay Social Security? The Impact of Mortality, Interest Rates, and Program Rules

John B. Shoven and Sita Nataraj Slavov

NBER Working Paper No. 18210

July 2012

JEL No. D14,H55

\begin{abstract}
Social Security benefits may be commenced at any time between ages 62 and 70 . As individuals who claim later can, on average, expect to receive benefits for a shorter period, an actuarial adjustment is made to the monthly benefit to reflect the age at which benefits are claimed. In earlier work (Shoven and Slavov, 2012), we investigated the actuarial fairness of this adjustment for individuals with average life expectancy for their cohort. We found that for current real interest rates, delaying is actuarially advantageous for a large subset of people, particularly for primary earners in married couples. In this paper, we quantify the degree of actuarial advantage or disadvantage for individuals whose mortality differs from the average. We find that at real interest rates close to zero, most households - even those with mortality rates that are twice the average - benefit from some delay, at least for the primary earner. At real interest rates closer to their historical average, however, singles with mortality that is substantially greater than average do not benefit from delay; however, primary earners with high mortality can still improve the present value of the household's benefits through delay. We also investigate the extent to which the actuarial advantage of delay has grown since the early 1960s, when the choice of when to claim first became available, and we decompose this growth into three effects: (1) the effect of changes in Social Security's rules, (2) the effect of changes in the real interest rate, and (3) the effect of changes in life expectancy.
\end{abstract}

John B. Shoven

Department of Economics

579 Serra Mall at Galvez Street

Stanford, CA 94305-6015

and NBER

shoven@stanford.edu

Sita Nataraj Slavov

American Enterprise Institute

1150 17th Street, NW

Washington, DC 20036

and NBER

sita.slavov@aei.org 


\section{Introduction}

Upon reaching the age of 62, most Americans face an important decision: when to claim Social Security benefits. While the vast majority of individuals claim immediately upon reaching age 62 or stopping work, claiming may be delayed until age 70. As Social Security benefits are paid as a life annuity, delayed claiming reduces the expected length of time over which benefits are claimed. Thus, the benefit calculation rules call for an actuarial adjustment so that individuals who claim later receive larger monthly payments. It is widely believed that this adjustment to benefits is actuarially fair, meaning that, on average, individuals can expect to receive the same present value of benefits regardless of when they claim. However, our recent work (Shoven and Slavov 2012) suggests that this claim is false, particularly in today's environment of near-zero real interest rates. Instead, delay appears to be actuarially advantageous for a very large subset of the population. The intuition behind this result is that delaying Social Security is equivalent to purchasing an annuity. An individual who delays forgoes benefits during the delay period in exchange for an increase in benefit payments for life. Private companies that sell annuities generally adjust their terms frequently, making payouts less generous when mortality improves (which increases the expected payout) or when interest rates fall (which reduces the return that can be earned on funds that are used to purchase the annuity). In contrast, the terms for delaying Social Security have, in many cases, become more generous over the past several decades despite improvements in life expectancy and fluctuations in real interest rates.

Our earlier work, which demonstrated that delay is actuarially advantageous in many cases, focused on individuals with average life expectancy. In this paper, we investigate the actuarial advantage or disadvantage of delay for individuals whose life expectancy differs from average. We compute the benefits from delay for single males, single females, one-earner couples, and 
two-earner couples from different race and education groups, using mortality rates that are differentiated by race and education. We also consider the benefits of delay for individuals who face higher mortality because of poor health (e.g., diabetes or smoking). We find that when real interest rates are close to zero, singles in all groups - even those with mortality that is substantially greater than average - gain from at least some delay. Couples in all groups benefit from delaying the primary earner's benefit, though for some groups with lower-than-average life expectancy, the couple maximizes present value when the secondary earner claims at age 62 . At real interest rates that are closer to their historical average, singles with substantially lower-thanaverage life expectancy no longer benefit from delays. However, even in this case couples in all groups gain from delaying the primary earner's benefit.

These results have important implications for financing retirement in the presence of defined contribution balances. Financial planners often advise individuals to use defined contribution balances to purchase an annuity, using the annuity income to supplement Social Security benefits. That is, the two retirement resources - Social Security and defined contribution balances - are consumed in parallel. However, in today's low-interest rate environment, this standard strategy is suboptimal for most retirees. The terms for delaying Social Security are more generous than the terms for purchasing a private annuity. Moreover, as Social Security payments are adjusted for cost-of-living increases, delaying Social Security buys an annuity whose payments remain constant in real terms; such annuities are virtually unavailable in the private market. This suggests that for individuals with defined contribution balances, accessing retirement resources in sequence - that is, using defined contribution accounts to finance a delay of Social Security - is likely to generate higher retirement income than using them in parallel. 
Delaying Social Security has not always been actuarially advantageous. The ability to choose the age at which to claim Social Security was introduced in 1956 for women and 1961 for men. Law changes in these years allowed individuals to claim benefits anytime between ages 62 and 65 , with an actuarial reduction for claiming before age 65 . Since then, the terms for delaying benefits from age 62 to age 65 have changed, particularly with regard to survivor benefits for couples. In addition to benefit rule changes, life expectancy has improved substantially between 1962 and the present, and interest rates have fluctuated. We find that the terms for delay between ages 62 and 65 were slightly actuarially disadvantageous in the early 1960s for those in average health, except for single women. Rule changes since that time have made delays slightly less attractive for singles and substantially more attractive for couples. The other two factors, the mortality improvements and the lower real interest rates, have substantially increased the attractiveness of delay for both singles and couples. The total effect is that some delay in commencing Social Security beyond age 62 is the right thing to do for the vast majority of retirees.

This paper is organized as follows. Section 2 summarizes the relevant literature. Section 3 presents our methodology and the gains from delay for a set of stylized households that differ in mortality. Section 4 examines the extent to which the gains from delay have changed since 1962, when delays were first possible for both men and women. Section 5 offers policy implications and conclusions.

\section{Literature}

Earlier studies have consistently found that, for real interest rates in the 2-3 percent range, delaying Social Security is actuarially advantageous for primary earners, mostly through its 
impact on survivor benefits (Meyer and Reichenstein 2010; Munnell and Soto 2005; Sass, Sun, and Webb 2007; Coile et al. 2002; Mahaney and Carlson 2007). Additionally, primary earners can collect benefits on their lower earning spouse's record while they delay their own benefit (Munnell, Sass, and Karamcheva 2009). Delay can also have tax advantages (Mahaney and Carlson 2007). However, the gains from delay are small at best for singles, particularly for single men (Jivan 2004; Munnell and Sass 2012). In earlier work (Shoven and Slavov 2012), we showed that at lower-than-average interest rates - and in particular, at the near-zero real interest rates that prevail today - singles and couples with average life expectancy stand to gain considerably through delay.

While studies of actuarial fairness focus on the expected present value of Social Security benefits at different claiming ages, Sun and Webb (2009) show that the utility value of delaying claiming may exceed the gain in expected present value because the additional Social Security benefits are paid as a real life annuity, insuring households against longevity and inflation risk. Along these lines, as Sass (2012) points out, private annuities available for purchase are necessarily actuarially unfair: a private insurance company that offered actuarially fair annuities would not be able to cover its administrative costs. Therefore, delaying Social Security - even if it is actuarially fair - can be better than buying a private annuity.

Despite the potential gains from delaying Social Security, most individuals appear to claim Social Security soon after they reach age 62 or stop work. Some studies have found that, although most individuals claim before the present-value maximizing age, there is a correlation between claiming age and the actuarial advantage of delay. For example, Coile et al. (2002) find that individuals with a longer life expectancy and a younger spouse (i.e., longer expected widow period) tend to delay. Munnell and Soto (2005) show that married women are most likely to 
claim early, followed by single men, married men, and single women, a finding that is consistent with the fact that secondary earners and single men derive the least benefit from delay. On the other hand, several other studies have found little relationship between claiming behavior and factors that influence the gains from delay (Hurd, Smith, and Zissimopolous 2004; Shoven and Slavov 2012; Sass, Sun, and Webb 2007). Field experiments suggest that informing people about the gains from delay do not change claiming behavior (Liebman and Luttmer 2011). However, the way in which the claiming decision is framed has a significant impact on individuals' self reports of their intended claiming age (Brown, Kapteyn, and Mitchell 2011).

Most of the earlier calculations of the gains from delay assume that individuals face average mortality risk. We are not aware of any calculations for individuals who face mortality rates that differ from average. That is the main contribution of the current paper. In addition, while a few earlier studies (Jivan 2004; Munnell and Sass 2012) have compared how the gains from delay have changed since the early 1960s when delays were first introduced, they focus on singles. Many of the rule changes that have occurred since then have made delay particularly advantageous for couples. Thus, an additional contribution of this paper is to provide a detailed analysis of how the gains from delay have changed for both singles and couples.

\section{Differential Mortality and the Gains from Delay}

\section{a. Benefit Rules}

Social Security benefits for a single individual are based on average indexed monthly earnings (AIME) which is defined as average monthly indexed earnings over the highest 35 years of indexed earnings, with the indexing reflecting average wage growth in the economy. The individual's base monthly Social Security benefit, called the Primary Insurance Amount 
(PIA) is derived by applying a progressive benefit formula to the AIME. Individuals in the 1950 birth cohort (who turn 62 in 2012) receive 90 percent of the first $\$ 767$ of AIME, 32 percent of AIME between $\$ 767$ and $\$ 4,624$, and 15 percent of any remaining AIME. The dollar amounts in the PIA formula - called "bend points" - are indexed for average wage growth in the economy. PIA is calculated at age 62 (based on the bend points in effect at that time) and indexed for price inflation thereafter. An individual is entitled to receive his or her PIA at full retirement age, which is 66 for individuals in the 1943-54 birth cohorts. Benefits may be claimed as early as 62 , but the benefit amount is reduced for each month of early claiming. An individual claiming at age 62 , for example, receives only 75 percent of his or her PIA. ${ }^{1}$ Delaying benefits beyond full retirement age - up to age 70 - results in a benefit increase of 8 percent of PIA per year of delay for individuals born in 1943 and later. Thus, claiming at age 70 results in a benefit amount that is 132 percent of PIA. In all cases, benefits are paid as an inflation-indexed life annuity.

A primary earner in a couple receives a benefit based on his or her own work record that is calculated in the same way as for singles. In a one-earner couple, the non-earner is entitled to a base benefit equal to 50 percent of the primary (only) earner's PIA at the non-earner's full retirement age. The spousal benefit may be claimed as early as age 62 , but the amount is reduced to 35 percent of the primary earner's PIA. There are no delayed retirement credits for spousal benefits. A spousal benefit may be claimed after the primary earner has claimed his or her own benefit, or reached full retirement age, whichever comes earlier. ${ }^{2}$ In two-earner couples,

\footnotetext{
${ }^{1}$ The full details of the reduction formula, for individuals born between 1943 and 1954, are available at http://www.ssa.gov/retirement/1943.html.

${ }^{2}$ Technically, a spousal benefit can only be claimed after the primary earner has claimed his or her own benefit. However, since 2000, a provision known as "file and suspend" has allowed primary earners to file for benefits upon reaching full retirement age and then immediately suspend their benefits. The primary earner's suspended benefits continue to grow through delayed retirement credits. This provision effectively allows a spouse to claim spousal benefits when the primary earner has reached full retirement age, regardless of whether the primary earner has started receiving his or her own benefits.
} 
both spouses can claim a benefit based on their own record. In addition, one spouse can claim a benefit based on the other spouse's record, subject to the same rules as the non-earner in oneearner couples. ${ }^{3}$ An individual who claims both a spousal benefit and a benefit based on his or her own work record receives the higher of the two amounts. Upon reaching full retirement age, individuals are allowed to "separate" their own benefits from their spousal benefits. That is, they may claim a spousal benefit at age 66 , then switch to their own benefit later, taking advantage of delayed retirement credits. As Shoven and Slavov (2012) demonstrate, for members of twoearner couples, the ability to claim a spousal benefit starting at age 66 dramatically reduces the costs of delaying one's own benefit to age 70 .

A widowed member of a couple is also entitled to collect a survivor's benefit based on the deceased spouse's earnings record. Individuals who claim their own benefits and survivor benefits receive the higher of the two amounts; thus, survivor benefits are typically only relevant to secondary earners. A widow can receive 71.5 percent of the primary earner's benefit (the primary earner's PIA plus any delayed retirement credits) at age $60 .{ }^{4}$ If the widow delays claiming, this amount is increased linearly - by 4.75 percent of the primary earner's benefit per year - until it reaches 100 percent of the primary earner's benefit amount at the widow's full retirement age (age 66 for individuals born between 1945 and 1956). ${ }^{5}$ However, if the primary earner claimed benefits before full retirement age - and was therefore receiving a reduced benefit at the time of death - the widow's benefit is limited to the maximum of the actual benefit received by the primary earner and 82.5 percent of the primary earner's PIA. This rule is known

\footnotetext{
${ }^{3}$ Either the primary or the secondary earner - but not both - may claim a spousal benefit based on the other person's record.

${ }^{4}$ If the primary earner died before claiming, the widow is entitled to the primary earner's PIA plus any delayed retirement credits the primary earner was entitled to at the time of death.

${ }^{5}$ Full details of the formula are available at http://www.ssa.gov/survivorplan/survivorchartred.htm
} 
as the "widow limit provision." For example, suppose the primary earner claimed at age 62, began receiving 75 percent of his PIA, and died. The widow would be entitled to collect 71.5 percent of the primary earner's PIA at age 60, 76.25 percent of the primary earner's PIA at age 62, and 81 percent of the primary earner's PIA at age 63. However, the widow's benefit cannot rise above 82.5 percent of the primary earner's PIA. Now suppose the primary earner claimed at age 64 , began receiving 86.7 percent of his PIA, and died. In this case, the widow would still be entitled to collect 71.5 percent of the primary earner's PIA at age 60 . This amount would still rise by 4.75 percent of the primary earner's PIA for each year that the widow delayed claiming. However, it would not rise beyond 86.7 percent of the primary earner's PIA. ${ }^{6}$ While the rules are complex, it should be clear that when a primary earner delays claiming, it increases survivor benefits for the secondary earner in the event of widowhood.

Conceptually, delaying Social Security is equivalent to purchasing an annuity. Delayed claiming requires one to forgo benefits during the delay period, in exchange for higher benefits for life. In addition, as the higher benefits are indexed for inflation, those who delay Social Security are effectively buying a real life annuity, which is virtually unavailable in the private market. When a single person delays claiming, he or she purchases a single life annuity, which pays benefits over the remainder of the individual's life. When the primary earner in a couple delays claiming, he or she purchases a joint life annuity with a 100 percent survivor benefit. That is, the annuity payments continue until the second person in the couple dies. When the secondary earner in a couple delays claiming, he or she purchases a first-to-die annuity, which pays benefits until either the primary earner dies (after which the secondary earner claims a widow benefit) or the secondary earner dies. All three kinds of annuities are offered on the same terms, even though a joint life annuity on average pays more benefits than a single life annuity,

\footnotetext{
${ }^{6}$ See Weaver (2002) and Shoven and Slavov (2012) for additional details.
} 
which on average pays more benefits than a first-to-die annuity. Moreover, the terms of these annuities do not vary based on a person's life expectancy, or on prevailing interest rates. In contrast, the terms of a private annuity typically vary based on life expectancy, interest rates, and the type of annuity (joint life, single life, or first-to-die) purchased. Thus, delaying Social Security is especially beneficial - relative to private annuities - when real interest rates are low, when an individual has above-average life expectancy, and when delay purchases a relatively generous joint life annuity.

\section{b. Methodology}

We simulate the gains from different delay strategies for a variety of stylized households differentiated by structure (single, one-earner couple, and two-earner couple) and mortality (based on either race and education, or on health status). For couples, the primary earner is assumed to be a male who turns 62 on January 1, 2013 (i.e., from the 1951 birth cohort), and the secondary earner is assumed to be a female who turns 60 on January 1, 2013 (i.e., from the 1953 birth cohort). In two-earner couples, the secondary earner's AIME is assumed to be 75 percent of the primary earner's AIME. Table 1 provides a list of the stylized households that we consider in our analysis. For singles, we consider males and females born on January 1, 1951 with mortality determined by the race/education and health categories given in the third column

of the table. For couples, we consider one-earner couples and two-earner couples with mortality given by the race and health categories given in the third column of the table. Both members of the couple are assumed to have the same race/education or health status, with the exception of the final case, in which the husband is assumed to be less healthy and the wife is assumed to be in average health. The last case is intended to illustrate that even if a primary earner faces 
higher-than-average mortality, the household can still benefit - through increased survivor benefits - if the primary earner delays claiming. We emphasize that our race-and-education differentiated mortality does not control for health status, and our health-differentiated mortality does not control for race or education. That is, some of the observed race/education differences in mortality arise from differences in health, and vice versa. Thus, an individual who is attempting to estimate how much he or she would gain from delay should use either the raceand-education differentiated results or the health-differentiated results, but not both.

We base our race-and-education differentiated mortality rates on the data presented in Brown, Liebman, and Pollet (2002). These data consist of mortality ratios for the race and education categories given in Table 1, broken down further by gender, based on matching data from the National Longitudinal Mortality Survey and the Current Population Survey. For each race-education-gender group, the mortality rate at age $a$ is equal to the probability of a group member dying before reaching age $a+l$ conditional on surviving to age $a$. The mortality ratio at age $a$ for a group is defined as the group's mortality rate at age $a$ relative to the mortality rate at age $a$ for the general population of the same gender. Figure 1 depicts mortality ratios for males aged 62 and older. For example, a mortality ratio of 1.95 for 62 -year-old black males with less than a high school education indicates that individuals in this group have a probability of dying before reaching age 63 , conditional on reaching their $62^{\text {nd }}$ birthday, that is 1.95 times that of all males aged 62 . Figure 2 provides the same information for females. The mortality rates calculated by Brown, Liebman, and Pollet (2002) are period mortality rates. If we assume that each group's mortality ratios remain constant over time, we can compute cohort life tables for 
each group by applying the mortality ratios to cohort life tables for the general population. ${ }^{7}$ Our cohort life tables come from the Social Security Administration, and are provided for men and women in each of the birth cohorts used in our analysis. The cohort life tables include mortality rates through age 119, while the Brown, Liebman, and Pollet (2002) mortality ratios are provided through age 100. We set each group's mortality ratio equal to 1 for ages greater than 100 .

In our simulations that differentiate mortality by health status, we assume that "less healthy" individuals have a mortality rate at each age that is twice that of the general population of the same gender. "Healthy" individuals have a mortality rate at each age that is 75 percent of that of the general population of the same gender. These assumptions are roughly consistent with available data on health-differentiated mortality. A report by the Society of Actuaries (2002) projects mortality rates for healthy and disabled individuals in the year 2000 based on data from company pension plans. These data suggest that disabled individuals have mortality rates that are roughly 1-3 times that of the general population between ages 62 and 89 . For example, according to the Society of Actuary mortality tables, disabled males aged 62 have a mortality rate of 4.5 percent. In comparison, according to Arias et al. (2010), the overall mortality rate for males aged 62 in 2000 was 1.5 percent, suggesting a mortality ratio of 3 for disabled men aged 62. At age 90 , this mortality ratio has fallen to roughly 1 . The ratios for women follow the same pattern. Similarly, the healthy individuals in the Society of Actuaries mortality tables have mortality ratios of roughly 0.6 ( 0.57 for men and 0.68 for women) at age 62 , rising to roughly 1 at age 89 .

For each of our stylized households, we compute the expected present value of benefits from every possible claiming strategy. We only consider claiming strategies that involve

\footnotetext{
${ }^{7}$ Brown, Liebman, and Pollet (2002) point out that this assumption may not be justified, as there is some evidence that group differences in mortality have been growing. In addition, the groups' shares in the general population would have shifted through time.
} 
claiming on birthdays, although adjustments to benefits are made on a monthly basis. For singles, a claiming strategy is straightforward, consisting only of an age at which to claim benefits. For couples, a claiming strategy is more complex. For one-earner couples, a claiming strategy includes an age for the primary earner to claim worker benefits and an age for the secondary earner to claim spousal benefits. For two-earner couples, a claiming strategy includes an age for each individual to claim worker benefits. In addition, whenever possible, one member of the couple claims spousal benefits starting at full retirement age. For example, a strategy for a two earner couple may involve the primary earner claiming worker benefits at age 70 , the secondary earner claiming worker benefits at age 66 , and the primary earner claiming spousal benefit at age 66 . As the primary earner has reached full retirement age, he can "separate" his spousal benefit from his worker benefit, claiming the spousal benefit at age 66 and allowing his worker benefit to grow through delayed retirement credits. On the other hand, if a strategy involves both members of the two-earner couple claiming worker benefits before age 66 , then neither is able to claim a spousal benefit. Deaths are assumed halfway through the year, and the widow is assumed to claim survivor benefits immediately. ${ }^{8}$ The widow is also assumed to follow through on his or her original plan for collecting worker benefits, and is paid the higher of the worker and survivor benefits if both have been claimed.

In computing present values, we use two alternative real discount rates - zero percent and 2.9 percent. Today's safe real interest rates are roughly zero - as of June 28,2012 , the interest rate on 10-year Treasury Inflation Protected Securities (TIPS) was -0.48 percent, and the interest rate on 30-year TIPS was 0.49 percent. $^{9}$ The long-term average of safe real interest rates is

\footnotetext{
${ }^{8}$ See Shuart, Weaver, and Whitman (2010) for an analysis of present value maximizing strategies for claiming widow benefits.

${ }^{9}$ See http://www.treasury.gov/resource-center/data-chart-center/interestrates/Pages/TextView.aspx?data=realyield.
} 
closer to 2.9 percent - indeed, this is the long-run real interest rate assumed by the Social Security actuaries in their projections of the program's finances.

\section{c. Results}

Intuitively, longer life expectancies should increase the gains from delaying Social Security. Thus, to frame our results, Table 2 indicates the remaining life expectancy for men and women in the 1950 birth cohort in each race-education and health status group, conditional on reaching age 62. From this table, it should be clear that of the race-education groups we consider, Hispanic women benefit the most from delay, while black men with less than a high school education benefit the least. For couples, the benefit from delay depends not only on the life expectancy of the primary earner, but also on the potential length of widowhood for the secondary earner. For our hypothetical couples, Table 3 presents the expected number of years to the first and second deaths, as well as the expected length of widowhood. The relative gains from delay are not as obvious for couples as for singles. For example, while black couples with less than a high school education have the shortest expected time to the first and second deaths, the expected length of widowhood is greater than average. In addition, while less healthy couples have a shorter-than-average expected time to the first and second deaths, as well as a shorter-than-average expected widowhood length, a less healthy husband and an average-health wife face a longer-than-average expected widowhood length.

Table 4 presents the claiming strategies that maximize the net expected present value (NPV) of benefits for each of our stylized singles, as well as the percent gain in NPV relative to claiming at age 62 . At a zero percent real interest rate, all singles - even those with mortality rates that are twice the average (the less healthy group) - benefit from delay. Of course, the 
NPV-maximizing delays are shorter for groups with higher mortality rates. While the average woman maximizes NPV by delaying to age 70, a less healthy male maximizes NPV by delaying only to age 65 . As expected, white college-educated women gain the most from delay, while less healthy men stand to gain very little.

Table 5 presents the NPV-maximizing claiming strategies for each of our stylized couples, as well as the percent gain in NPV relative to both members of the couple claiming at age 62. Although not shown in the table, for every strategy involving delays beyond age 66 , one member of each two-earner couple starts spousal benefits at age 66. For example, at a zero percent real interest rate, both members of two-earner couples with average (or better) mortality should delay to age 70 to maximize NPV. In addition, the secondary earner should begin spousal benefits at age 66 . On the other hand, if the primary earner delays to age 70 while the secondary earner collects benefits earlier, then the primary earner should begin spousal benefits at age 66 .

One striking results from Table 5 is that primary earners in two-earner couples - even those with life expectancies that are far below average - should always delay to age 70 to maximize NPV. This result applies even if interest rates are close to their historical average. The gains from delaying are so large for primary earners for two reasons. First, delays by the primary earner boost the survivor benefits of the secondary earner; that is, when a primary earner delays benefits, he is effectively buying a second-to-die or joint life annuity, which is much more valuable than the single-life annuity that a single receives from delay (this is a benefit that applies to one-earner couples as well). Second, primary earners who delay beyond full retirement age can collect a spousal benefit during the delay period (this benefit applies only to two-earner couples). In contrast, when a secondary earner delays benefits, she is effectively buying a first-to-die annuity, whose benefit ends when either she dies or when her husband dies 
(and she switches to widow benefits). A first-to-die annuity is much less valuable than either a single-life or a second-to-die annuity. Thus, when interest rates are close to their historical average ( 2.9 percent), secondary earners do not gain from delay at all. In one-earner couples, primary earners still benefit substantially from delay due to the higher survivor benefits.

However, the gains are not as large due to the fact that they cannot claim a spousal benefit during the delay period. At either interest rate, almost all of our one-earner couples (with the exception of the less healthy couple with twice the average mortality) gain from delaying the primary earner's benefit. However, the NPV maximizing delays are shorter at the higher interest rate.

The percent gain figures in Tables 4 and 5 don't immediately convey how much money is at stake in adopting an NPV-maximizing strategy rather than collecting Social Security as soon as possible. In order to translate these possible percentage gains into actual dollars, one needs to know the expected present value of Social Security for the base case of commencing benefits at 62. Assuming a zero percent real interest rate and average life expectancy, the NPV of Social Security (commenced at age 62) is around 200 times the PIA for singles ${ }^{10}$ and around 350 times the PIA of the primary earner for couples. ${ }^{11}$ The average PIA is around $\$ 1,500$. Therefore, the average single can expect to receive around $\$ 300,000$ from Social Security, while the average couple can expect to receive $\$ 525,000$. A single person who improves his or her NPV by 10 -20 percent through delay stands to gain $\$ 30,000-60,000$. A couple stands to gain even more roughly 20-25 percent, which translates into dollar gains of around $\$ 100,000-\$ 130,000$. Higherearning individuals - who have higher PIAs - and those with above average health and therefore below average mortality obviously stand to gain even more. The largest gain we have

\footnotetext{
${ }^{10}$ Females receive an NPV of 202.2 times their PIA, and males receive an NPV of 191.6 times their PIA.

${ }^{11}$ One-earner couples receive 334.0 times the earner's PIA, and two-earner couples receive 373.6 times the primary earner's PIA.
} 
encountered is approximately $\$ 250,000$. We emphasize that the amounts of money involved are substantial. Many of these gains are larger than the average $401(\mathrm{k})$ balance at the time of retirement.

\section{The Gains from Delay: 1962 versus 2013}

The terms for delaying Social Security have not always been this attractive. Prior to 1956, all individuals had to claim Social Security at age 65, the normal retirement age. The 1956 amendments to the Social Security act allowed women to claim a reduced worker or spousal benefit starting at age 62. The same provision began to apply to men starting on August 1, 1961 . Worker benefits claimed at age 62 were reduced to 80 percent of the individual's PIA, and spousal benefits claimed at age 62 were reduced to 37.5 percent of the working spouse's PIA. The benefit reduction formulas for worker and spousal benefits that were introduced in 1956 and 1961 are essentially the same as the ones in place today, although the normal retirement age has risen to 66. However, survivor benefits did not depend on the claiming age of either the widow or the deceased spouse. Under the 1961 amendments, a widow could receive 82.5 percent of the deceased spouse's PIA starting at age 62. Credits for delaying Social Security beyond full retirement age were not introduced until 1972. In addition, real interest rates were higher in the early 1960 s than they are today. The average real interest rate over 1960-1965, as reported by the Social Security Trustees, was 2.5 percent. $^{12}$

To provide an idea of how the terms for delay have changed over time, we compute the gain from delaying benefits from age 62 to age 65 under current conditions (rules, interest rates, and life expectancy), and under the conditions that prevailed in 1962. We perform this

\footnotetext{
${ }^{12}$ See table V.B2 of the 2011 Trustee's Report, available at http://www.ssa.gov/oact/tr/2011/V B econ.html\#223125.
} 
calculation for single men and women, as well as for a single-earner couple and a two-earner couple. The singles are assumed to be 62 in the year of computation. The husband in each couple is assumed to be 62 , and the wife 60 , in the year of computation. For couples, we consider the gains from delaying both individuals' benefits, as well as the gains from delaying only the primary earner's benefit. All individuals are assumed to face average mortality risk for their cohort.

The top panel (“Actual: 2013”) of Table 6 indicates the gains from delay under 2013 rules, life expectancy, and real interest rates (zero percent). The gains are substantial in all cases, but particularly for one-earner couples and single women. In this calculation, the gains are greater for one-earner couples than two-earner couples because we are considering only delays to age 65. The main advantage for two earner couples - as seen in table 5 - occurs for delays after full retirement age, as one individual can claim a spousal benefit during that delay period. One earner couples gain the most when both spouses defer their benefit, as the gains from delaying a spousal benefit to age 65 are particularly large. The second panel (“Actual: 1962”) of Table 6 indicates the gains from delay under 1962 rules, life expectancy, and interest rates (2.5 percent). While delays were slightly advantageous for single females, single males and couples actually benefited from claiming early.

To tease out the effects of life expectancy improvements, interest rates, and rule changes, the third panel (“Counterfactual 1") of Table 6 presents the gains from delay under 2013 rules and real interest rates (zero percent) combined with 1962 mortality. Comparing the third panel with the first panel shows the impact of life expectancy improvements between 1962 and 2013. The gains from delay have increased most dramatically for men, with women and couples realizing moderate increases. This result is consistent with the fact that male mortality has 
improved more than female mortality over the period. The fourth panel ("Counterfactual 2") of Table 6 presents the gains from delay under 2013 rules, combined with 1962 real interest rates and life expectancy. Comparing the third and fourth panels isolates the impact of the higher real interest rate in 1962, which sharply reduces the gains from delay for both singles and couples. Finally, comparing the fourth panel ("Counterfactual 2") with the second panel (“Actual: 1962") reveals the effects of the rule changes that occurred between 1962 and today. The only rule change affecting singles has been a modest increase in the full retirement age, from 65 to 66 . This change slightly reduced the gains from delay. For couples, rule changes have significantly increased the gains from delay. The generosity of the survivor benefit was increased in 1972, allowing a widow to receive up to 100 percent of the deceased spouse's PIA. However, the maximum benefit a widow could receive was constrained by the actual benefit the deceased spouse was receiving (the widow limit provision). Thus, widow benefits became sensitive to the claiming decision of the deceased spouse.

\section{Conclusions}

We have shown that for real interest rates close to zero, delaying receipt of Social Security is actuarially advantageous for a large fraction of households, even those with mortality rates that are twice the average. At real interest rates closer to their historical average, delay is not actuarially advantageous for single individuals with mortality that is substantially above average; however, for married couples, primary earners with above-average mortality can gain from delay by passing on a higher survivor benefit to their spouses. The gains from delay have increased dramatically since the early 1960s, when delay first became available. This increase is due to three factors. First, life expectancy has increased since the early 1960s. Second, changes 
to Social Security's rules have made delay more advantageous for couples (although slightly less advantageous for singles). Third, real interest rates have fallen to approximately zero.

The actuarial fairness of the adjustment for delaying benefits has implications for Social Security's finances. A large number of individuals claim at age 62 or soon after, and very few individuals delay claiming beyond their full retirement age. In fact, there is little evidence that individuals currently choose their claiming ages to maximize the present value of their Social Security benefits (see Shoven and Slavov, 2012). Holding labor force participation constant, we would expect Social Security's finances to deteriorate if individuals began delaying claiming in a manner that maximized the present value of their benefits. This effect is possible if delays were financed by spending down defined contribution balances. However, delayed claiming may also encourage older people to remain in the labor force longer, using labor income to finance the delay. This effect would tend to boost payroll tax revenue and improve Social Security's finances (not to mention the increase is federal income tax proceeds). Indeed this effect has been cited as a rationale for increasing the generosity of the delayed retirement credit, and it underlies proposals for making the delayed retirement credit more attractive by paying it as a lump sum (Orszag 2001; Blahous 2010). Estimating the net effect of delayed claiming is beyond the scope of this paper, as it would require knowledge of the interaction between Social Security claiming and labor supply choices. However, we believe it would be a worthwhile question for future research. 


\section{References}

Arias, Elizabeth, Brian L. Rostron, and Betzaida Tejada-Vera. 2010. "United States Life Tables, 2005." National Vital Statistics Reports 58(10).

Blahous, Charles. 2010. Social Security: The Unfinished Work. Stanford: Hoover Institution Press.

Brown, Jeffrey, R., Arie Kapteyn, and Olivia Mitchell. 2011. "Framing Effects and Expected Social Security Claiming Behavior." Working Paper 17018. Cambridge: National Bureau of Economic Research.

Brown, Jeffrey R., Jeffrey B. Liebman, and Joshua Pollet. 2002. "Estimating Life Tables That Reflect Socioeconomic Differences in Mortality." In The Distributional Aspects of Social Security and Social Security Reform, eds. Martin Feldstein and Jeffrey B. Liebman. Chicago: University of Chicago Press.

Coile, Courtney, Peter Diamond, Jonathan Gruber and Alain Jousten. 2002. "Delays In Claiming Social Security Benefits." Journal of Applied Econometrics 84(3): 357-385.

Hurd, Michael D., James P. Smith and Julie M. Zissimopoulos. 2004. "The Effects of Subjective Survival on Retirement and Social Security Claiming." Journal of Applied Econometrics 19(6): 761-775.

Jivan, Natalia A. 2004. "How Can the Actuarial Reduction for Social Security Be Right?” Just the Facts 11, Center for Retirement Research. Chestnut Hill: Boston College.

Liebman, Jeffrey B. and Erzo F.P. Luttmer. 2011. "Would People Behave Differently If They Better Understood Social Security? Evidence From a Field Experiment.” Unpublished Manuscript.

Mahaney, James I. and Peter C. Carlson. 2007. "Rethinking Social Security Claiming in a 401(k) World.” Working Paper 2007-18. Philadelphia: Pension Research Council.

Meyer, William and William Reichenstein. 2010. "Social Security: When to Start Benefits and How to Minimize Longevity Risk." Journal of Financial Planning 23(3): 49-59.

Munnell, Alicia H., Alex Golub-Sass and Nadia Karamcheva, N. 2009, "Strange but True: Claim Social Security Now, Claim More Later." Issue Brief 9-9, Center for Retirement Research. Chestnut Hill: Boston College.

Munnell, Alicia H. and Mauricio Soto. 2005. "Why Do Women Claim Social Security Benefits So Early?" Issue Brief 35, Center for Retirement Research. Chestnut Hill: Boston College. 
Orszag, Peter. 2001. "Should a Lump-Sum Payment Replace Social Security's Delayed Retirement Credit?" Issue in Brief 6, Center for Retirement Research. Chestnut Hill: Boston College.

Sass, Steven A., Wei Sun, and Anthony Webb. 2007. "Why Do Men Claim Social Security So Early: Ignorance or Caddishness?" Working Paper 2007-17, Center for Retirement Research. Chestnut Hill: Boston College.

Society of Actuaries. 2000. "The RP-2000 Mortality Tables.” Retrieved from http://www.soa.org/research/experience-study/pension/research-rp-2000-mortalitytables.aspx.

Sun, Wei and Anthony Webb. 2009. "How Much Do Households Really Lose by Claiming Social Security at Age 62?" Unpublished Manuscript.

Shuart, Amy N., David A. Weaver, and Kevin Whitman. 2010. "Widowed Before Retirement: Social Security Benefits Claiming Strategies." Journal of Financial Planning 23(4): 45-53.

Weaver, David A. 2002. "The Widow(er)'s Limit Provision of Social Security." Social Security Bulletin 64(1): 1-15. 
Figure 1: Mortality Ratios for Race-Education Groups - Males

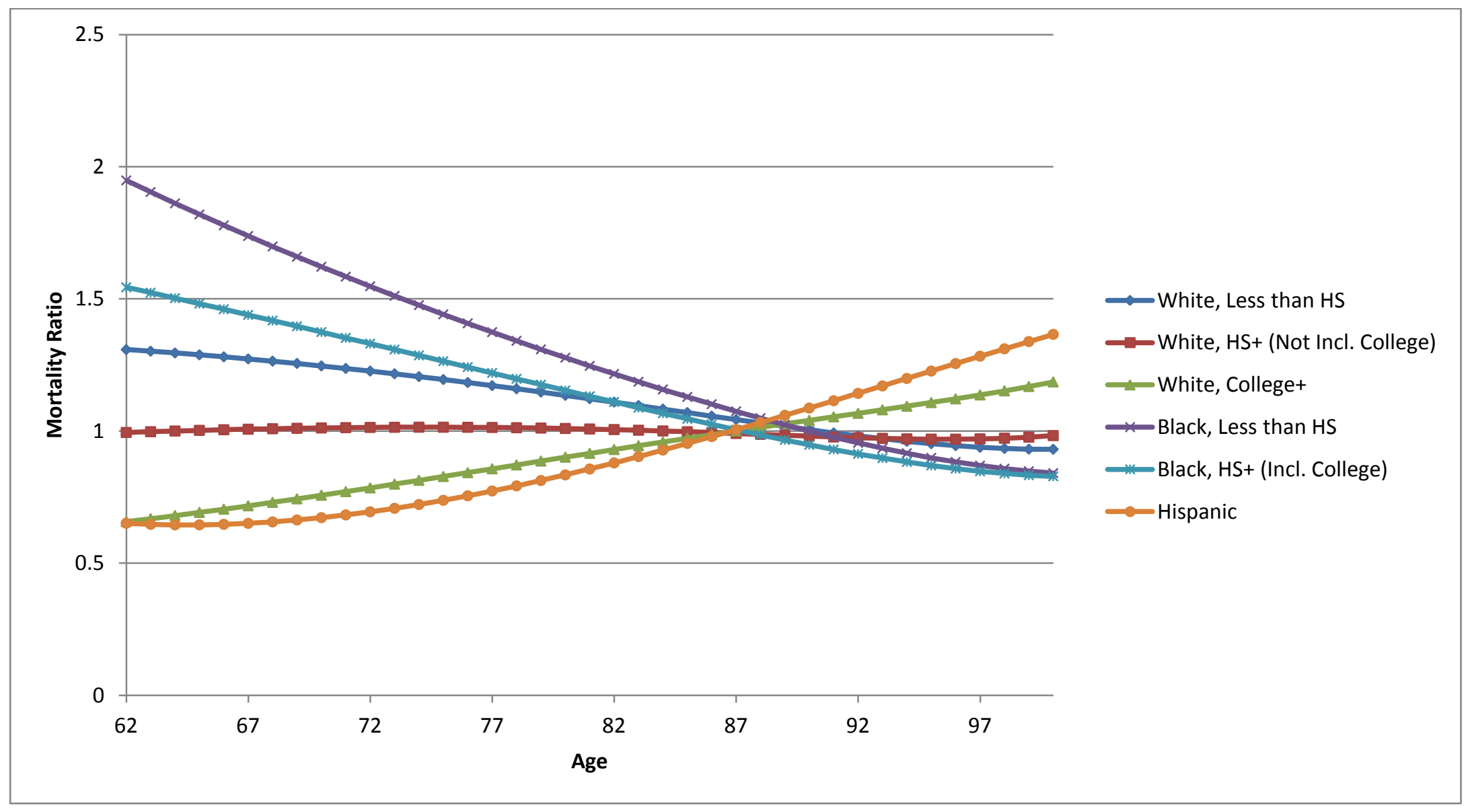

Notes: Ratios are from Brown, Liebman, and Poulet (2002). 
Figure 2: Mortality Ratios for Race-Education Groups - Females



Notes: Ratios are from Brown, Liebman, and Poulet (2002). 
Table 1: Stylized Households

\begin{tabular}{lll}
\hline Marital Status & Type & Mortality \\
\hline Singles & Male & All Individuals \\
& Female & White, Less than HS \\
& & White, HS+ (Not Incl. College) \\
& White, College \\
& Black, Less than HS \\
& Black, HS+ (Incl. College) \\
& Hispanic \\
\hline Couples & Healthy \\
& Less Healthy \\
& One-Earner & All Individuals \\
& Wwo-Earner & White, Less than HS \\
& White, HS+ (Not Incl. College) \\
& White, College \\
& Black, Less than HS \\
& Black, HS+ (Incl. College) \\
& Hispanic \\
\hline & Healthy \\
& Less Healthy \\
& Less Healthy Husband, Avg. \\
& Wife \\
\hline &
\end{tabular}


Table 2: Remaining Life Expectancy at Age 62

\begin{tabular}{lrr}
\hline & Male & Female \\
\hline All Individuals & 21.29 & 23.58 \\
White, Less than HS & 20.01 & 22.64 \\
White, HS+ (Not Incl. College) & 21.27 & 23.60 \\
White, College & 22.49 & 24.49 \\
Black, Less than HS & 18.29 & 20.91 \\
Black, HS+ (Incl. College) & 19.56 & 22.60 \\
Hispanic & 22.86 & 24.74 \\
Healthy & 23.82 & 26.11 \\
Less Healthy & 15.66 & 17.95 \\
\hline
\end{tabular}


Table 3: Average Length of Time Until First- and Second-to-Die (Couple Aged 62/60)

\begin{tabular}{lrrr}
\hline & $\begin{array}{c}\text { Years to 1st } \\
\text { Death }\end{array}$ & $\begin{array}{c}\text { Years to 2nd } \\
\text { Death }\end{array}$ & Widowhood \\
\hline All Individuals & 17.50 & 29.17 & 11.68 \\
White, Less than HS & 16.13 & 28.26 & 12.14 \\
White, HS+ (Not Incl. College) & 17.55 & 29.15 & 11.60 \\
White, College & 18.95 & 29.91 & 10.95 \\
Black, Less than HS & 13.96 & 26.77 & 12.80 \\
Black, HS+ (Incl. College) & 15.51 & 28.32 & 12.82 \\
Hispanic & 19.28 & 30.19 & 10.91 \\
Healthy & 19.81 & 32.00 & 12.19 \\
Less Healthy & 12.40 & 22.83 & 10.44 \\
Less Healthy Husband, Avg. Wife & 13.81 & 27.23 & 13.42 \\
\hline
\end{tabular}


Table 4: NPV-Maximizing Strategies for Singles

\begin{tabular}{|c|c|c|c|c|c|}
\hline & \multirow[t]{2}{*}{ Real Interest Rate } & \multicolumn{2}{|c|}{$\mathbf{r}=\mathbf{0} \%$} & \multicolumn{2}{|c|}{$\mathrm{r}=2.9 \%$} \\
\hline & & $\begin{array}{c}\text { NPV- } \\
\text { Maximizing } \\
\text { Strategy }\end{array}$ & $\begin{array}{c}\% \\
\text { Gain } \\
\end{array}$ & $\begin{array}{c}\text { NPV- } \\
\text { Maximizing } \\
\text { Strategy }\end{array}$ & $\begin{array}{c}\% \\
\text { Gain }\end{array}$ \\
\hline \multirow[t]{10}{*}{ Males } & All Individuals & 69 & $13.5 \%$ & 65 & $1.3 \%$ \\
\hline & White, Less than HS & 69 & $10.9 \%$ & 65 & $0.3 \%$ \\
\hline & White, HS+ (Not Incl. & & & & \\
\hline & College) & 69 & $13.4 \%$ & 65 & $1.3 \%$ \\
\hline & White, College & 70 & $15.7 \%$ & 67 & $2.8 \%$ \\
\hline & Black, Less than HS & 68 & $7.6 \%$ & 62 & $0.0 \%$ \\
\hline & Black, HS+ (Incl. College) & 69 & $10.2 \%$ & 62 & $0.0 \%$ \\
\hline & Hispanic & 70 & $16.6 \%$ & 67 & $3.4 \%$ \\
\hline & Healthy & 70 & $19.3 \%$ & 68 & $4.4 \%$ \\
\hline & Less Healthy & 65 & $1.5 \%$ & 62 & $0.0 \%$ \\
\hline \multirow[t]{10}{*}{ Females } & All Individuals & 70 & $18.4 \%$ & 68 & $4.1 \%$ \\
\hline & White, Less than HS & 70 & $16.6 \%$ & 67 & $2.9 \%$ \\
\hline & White, HS+ (Not Incl. & & & & \\
\hline & College) & 70 & $18.4 \%$ & 68 & $4.1 \%$ \\
\hline & White, College & 70 & $20.1 \%$ & 68 & $5.4 \%$ \\
\hline & Black, Less than HS & 70 & $13.4 \%$ & 65 & $0.9 \%$ \\
\hline & Black, HS+ (Incl. College) & 70 & $16.9 \%$ & 67 & $2.7 \%$ \\
\hline & Hispanic & 70 & $20.7 \%$ & 68 & $5.7 \%$ \\
\hline & Healthy & 70 & $23.6 \%$ & 68 & $7.3 \%$ \\
\hline & Less Healthy & 68 & $5.6 \%$ & 62 & $0.0 \%$ \\
\hline
\end{tabular}


Table 5: NPV-Maximizing Strategies for Couples

\begin{tabular}{|c|c|c|c|c|c|c|c|}
\hline & \multirow[t]{2}{*}{ Real Interest Rate } & \multicolumn{3}{|c|}{$\mathrm{r}=0 \%$} & \multicolumn{3}{|c|}{$r=2.9 \%$} \\
\hline & & $\begin{array}{c}\text { Husband's } \\
\text { NPV- } \\
\text { Maximizing } \\
\text { Age }\end{array}$ & $\begin{array}{c}\text { Wife's } \\
\text { NPV- } \\
\text { Maximizing } \\
\text { Age }\end{array}$ & $\%$ Gain & $\begin{array}{c}\text { Husband's } \\
\text { NPV- } \\
\text { Maximizing } \\
\text { Age }\end{array}$ & $\begin{array}{c}\text { Wife's } \\
\text { NPV- } \\
\text { Maximizing } \\
\text { Age }\end{array}$ & \% Gain \\
\hline \multirow{11}{*}{$\begin{array}{l}\text { One- } \\
\text { Earner }\end{array}$} & & & & & & & \\
\hline & All Individuals & 70 & 66 & $20.5 \%$ & 69 & 65 & $7.1 \%$ \\
\hline & White, Less than HS & 70 & 66 & $18.7 \%$ & 69 & 65 & $5.6 \%$ \\
\hline & White, HS+ (Not Incl. College) & 70 & 66 & $20.5 \%$ & 69 & 65 & $7.1 \%$ \\
\hline & White, College & 70 & 66 & $22.1 \%$ & 70 & 66 & $8.5 \%$ \\
\hline & Black, Less than HS & 70 & 65 & $15.8 \%$ & 69 & 64 & $3.3 \%$ \\
\hline & Black, HS+ (Incl. College) & 70 & 66 & $18.4 \%$ & 69 & 64 & $5.3 \%$ \\
\hline & Hispanic & 70 & 66 & $22.6 \%$ & 70 & 66 & $9.0 \%$ \\
\hline & Healthy & 70 & 66 & $24.7 \%$ & 70 & 66 & $10.6 \%$ \\
\hline & Less Healthy & 70 & 64 & $8.5 \%$ & 62 & 62 & $0.0 \%$ \\
\hline & Less Healthy Husband, Avg. Wife & 70 & 65 & $14.5 \%$ & 69 & 64 & $2.8 \%$ \\
\hline \multirow{11}{*}{$\begin{array}{l}\text { Two- } \\
\text { Earner }\end{array}$} & & & & & & & \\
\hline & All Individuals & 70 & 70 & $22.2 \%$ & 70 & 62 & $11.8 \%$ \\
\hline & White, Less than HS & 70 & 64 & $20.7 \%$ & 70 & 62 & $10.9 \%$ \\
\hline & White, HS+ (Not Incl. College) & 70 & 70 & $22.1 \%$ & 70 & 62 & $11.8 \%$ \\
\hline & White, College & 70 & 70 & $23.9 \%$ & 70 & 62 & $12.6 \%$ \\
\hline & Black, Less than HS & 70 & 62 & $19.2 \%$ & 70 & 62 & $9.5 \%$ \\
\hline & Black, HS+ (Incl. College) & 70 & 64 & $20.6 \%$ & 70 & 62 & $10.8 \%$ \\
\hline & Hispanic & 70 & 70 & $24.6 \%$ & 70 & 62 & $12.9 \%$ \\
\hline & Healthy & 70 & 70 & $26.8 \%$ & 70 & 62 & $13.9 \%$ \\
\hline & Less Healthy & 70 & 62 & $13.8 \%$ & 70 & 62 & $5.2 \%$ \\
\hline & Less Healthy Husband, Avg. Wife & 70 & 62 & $17.8 \%$ & 70 & 62 & $8.6 \%$ \\
\hline
\end{tabular}


Table 6: Gains from Delaying to Age 65

Actual: 2013

Single Male

$7.24 \%$

Single Female

$8.80 \%$

One-Earner Couple

Both Delay

$8.26 \%$

Primary Delays

$6.81 \%$

Two-Earner Couple

Both Delay

$6.73 \%$

Primary Delays

$6.15 \%$

Actual: 1962

Single Male

$-3.98 \%$

Single Female

$1.61 \%$

One-Earner Couple

Both Delay

$-3.15 \%$

Primary Delays

$-2.23 \%$

Two-Earner Couple

Both Delay

$-4.72 \%$

Primary Delays

$-1.96 \%$

\section{Counterfactual 1: 2013 Rules and Real Interest} Rate, 1962 Mortality

Single Male

$0.84 \%$

Single Female

$6.31 \%$

One-Earner Couple

Both Delay

$3.75 \%$

Primary Delays

$3.99 \%$

Two-Earner Couple

Both Delay

$2.29 \%$

Primary Delays

$3.78 \%$

Counterfactual 2: 2013 Rules, 1962 Mortality and Real Interest Rate

\begin{tabular}{llr} 
Single Male & & $-4.40 \%$ \\
Single Female & & $1.16 \%$ \\
One-Earner Couple & Both Delay & $-0.55 \%$ \\
& Primary Delays & $0.60 \%$ \\
Two-Earner Couple & Both Delay & $-2.10 \%$ \\
& Primary Delays & $0.73 \%$ \\
\hline
\end{tabular}

